\title{
Memorias, ensayos y polémicas. El balance de la experiencia montonera en los años 80
}

Esteban Campos*

\section{RESUMO}

Neste artigo são investigadas as produções historiográficas, testemunhais e ensaísticas sobre a organização armada Montoneros na década de 1980. Na Argentina, as décadas de 1960 e 1970 foram um período de alta conflitividade, diante do que ainda hoje parece impossível resistir à tentaçáo de emitir uma prescriçáo moral. De onde se origina a tendência a julgar os movimentos armados que atuaram na Argentina? Para responder esta pergunta, incorporaremos a antropologia cultural de Marvin Harris como marco teórico e disciplina auxiliar, em particular as categorias emic e etic, que são empregadas para compreender as atitudes do investigador de campo. Assim poderemos compreender as diversas formas de "empatia" e "antipatia" para com os movimentos armados, entendendo estas reaçóes como uma tomada de distância ou um apego estreito com respeito às categorias nativas do objeto de estudo. Abordaremos quatro livros sobre os Montoneros e a violência política: Soldados de Perón. Los Montoneros, de Richard Gillespie (1982), Montoneros. La soberbia armada, de Pablo Giussani (1984), La Argentina que quisieron, de Carlos Brocato (1985) e Montoneros. Final de cuentas, de Juan Gasparini (1988).

Palavras-chave: Montoneros; emic; etic; categorias nativas; passado recente.

\section{RESUMEN}

En este artículo se indagan las producciones historiográficas, testimoniales y ensayísticas sobre la organización armada Montoneros en la década de 1980. En la Argentina, las décadas de 1960 y 1970 fueron un período de alta conflictividad, ante el que todavía hoy parece imposible resistir la tentación de emitir una prescripción moral. ¿De dónde proviene la tendencia a juzgar los movimientos armados que actuaron en la Argentina? Para responder ésta pregunta, incorporaremos como marco teórico y disciplina auxiliar a la antropología cultural de Marvin Harris, en particular las categorías emic y etic que se emplean para comprender las actitudes del investigador de campo. Así podremos comprender las diversas formas de "empatía" y "antipatía" hacia los movimientos armados, entendiendo estas reacciones como una toma de distancia o un apego estrecho respecto de las categorías nativas del objeto de estudio. Tomaremos cuatro libros sobre los Montoneros y la violencia política: Soldados de Perón. Los Montoneros, de Richard Gillespie (1982), Montoneros. La soberbia armada, de Pablo Giussani (1984), La Argentina que quisieron, de Carlos Brocato (1985) y Montoneros. Final de cuentas, de Juan Gasparini (1988).

Palabras clave: Montoneros; emic; etic; categorías nativas; pasado reciente. 


\begin{abstract}
This article investigates the historiography production, witness depositions and essays on the armed organization Montoneros in the 1980s. In Argentina, the 1960s and the 1970s were a highly conflictive period, in face of which, still today, it is difficult to resist the temptation to issue a moral evaluation. Where does the tendency to judge Argentinean armed movements come from? To answer that question, we will incorporate Marin Harris' cultural anthropology as a theoretical framework and auxiliary discipline, in particular the categories emic and etic, which are employed to understand the field researcher's attitudes. Thus we will be able to understand the many forms of "empathy" and "antipathy" toward the armed movements, understanding these reactions as a distancing or a tight adhesion to the native categories of the study object. This article deals with four books on the Montoneros and political violence: Richard Gillespie's Soldados de Perón. Los Montoneros (1982), Pablo Giussani's Montoneros. La soberbia armada (1984), Carlos Brocato's La Argentina que quisieron (1985), and Juan Gasparini's Montoneros. Final de cuentas (1988).
\end{abstract}

Keywords: Montoneros; emic; etic; native categories; recent past. 
Pensé en mi actual actitud frente al trabajo etnográfico y los nativos. Lo poco que me gustan, y mi añoranza de la civilización (...) Estaba harto de los negros, y de mi trabajo.

Bronislaw Malinowsky. Diario de campo en Melanesia (1917).

A partir de la transición democrática que se inició en la Argentina hacia 1983, los conflictivos años 60 y 70 se volvieron un objeto caliente, marcando una profunda sutura entre el pasado y el presente. Un recodo temporal ante el cual todavía hoy parece imposible resistir la tentación de emitir una prescripción moral, ya sea porque quienes escriben sobre historia reciente pertenecen a la generación que cobijo a la nueva izquierda, o bien porque los jóvenes investigadores que no vivieron aquella época siguen sus huellas. Esta tendencia se manifiesta de manera frecuente como empatía o antipatía frente a los movimientos armados que actuaron entre 1959 y 1989, un tema que para la historiografía académica, así como para buena parte de la sociedad, sigue siendo el hecho maldito de un pasado que se resiste a ser olvidado. ${ }^{1}$ La empatía se manifiesta en la imposibilidad de apartarse de la perspectiva de los actores de aquel pasado que se quiere analizar o evocar, algo comprensible cuando leemos narraciones testimoniales que hablan en primera persona desde el lugar de verdad del "yo-lo-viví". Un buen ejemplo de esta tendencia son los libros de Miguel Bonasso, Daniel de Santis, Roberto Perdía y Ernesto Jauretche, en una clave narrativa más o menos épica y, según el caso, más o menos documentados. ${ }^{2}$ La antipatía, por el contrario, resulta del extrańamiento cultural de aquello que se percibe como la "locura" y el "mesianismo" guerrilleros, tópicos que vuelven irracional e ininteligible la experiencia de lucha armada en la Argentina. Es difícil separar esta toma de distancia de la crítica generacional a la opción por las armas, que conduce desde los 80 un sector del progresismo intelectual, vinculado a las instituciones universitarias. Entre los miembros más ilustres de esta camada se encuentran Beatriz Sarlo, Carlos Altamirano y Hugo Vezzetti. ${ }^{3}$

¿De dónde provienen estas tendencias que, en cierta medida, contribuyeron a fundar el campo de la joven Historia reciente? En la década de los 80, revistas como Controversia y Punto de Vista expresaron la toma de distancia como una autocrítica de la militancia setentista, en medio del naufragio político provocado por el terrorismo de Estado. El proyecto de refundación democrática inaugurado por el presidente Raúl Alfonsín, en cambio, incluyó la crítica de la violencia política como un argumento para la defensa de las instituciones liberales, síntoma de un cambio de época que aún no se adivinaba como algo perdurable. La imagen de una guerrilla enajenada de la sociedad se erigió como uno de los soportes de la teoría de los dos demonios, formalizada en el prólogo del informe de la Comisión Nacional sobre la

\footnotetext{
${ }^{1}$ Para Omar Acha, en los 80 el peronismo dejó de ser motivo de crispación para el campo académico, y fue presentado como un capítulo de la modernización argentina: "La vertebración de una matriz progresista fue consustancial a la institucionalización del campo historiográfico durante las dos últimas décadas del siglo veinte. Lo que hasta entonces había sido percibido como anomalías, debían ser 'comprendidas' (...) Todo campo histórico se afana en neutralizar lo 'monstruoso', que no piensa como productividad de la vida histórica sino como obstáculo epistemológico a superar”. Lo monstruoso, la alteridad radical incapaz de ser comprendida por la historiografía, entonces, paso a ser la violencia política de los 70 y el terrorismo de Estado, v. ACHA, Omar. Un revisionismo histórico de izquierda. Buenos Aires: Herramienta, 2012. p. 124. ${ }^{2}$ MANZANO, Valeria. "Betrayal, loyalty, the Peronist People and the forgotten archives: Miguel Bonasso's narrative and the Peronist Left's political culture, 1984-2003. Journal of Latin American Studies, Bloomington, v. 16, Issue 2, 2007; DE SANTIS, Daniel. A vencer o morir. PRT-ERP Documentos (v. 1). Buenos Aires: Eudeba, 1998; PERDÍA, Roberto. La otra historia. Testimonio de un jefe montonero. Buenos Aires: Agora, 1997. LEVENSON, Gregorio; JAURETCHE, Ernesto. Héroes. Historias de la Argentina revolucionaria. Buenos Aires: Colihue, 1998.

${ }^{3}$ ACHA, Omar. "Dilemas de una violentología argentina”. In: ACHA, Omar. Un revisionismo histórico de izquierda, op. cit., p. 167-193; SARLO, Beatriz. La pasión y la excepción. Eva, Borges y el asesinato de Aramburu. Buenos Aires: Siglo XXI, 2003; VEZZETTI, Hugo. Sobre la violencia revolucionaria. Memorias y olvidos. Buenos Aires: Siglo XXI, 2009; ALTAMIRANO, Carlos. Peronismo y cultura de izquierda. Buenos Aires: Temas, 2001.
} 
Desaparición de Personas (Conadep). ${ }^{4}$ En la segunda mitad de los años 90, el incremento de las luchas sociales coincidió con un avance de las organizaciones de derechos humanos. Los movimientos sociales que aglutinaban a trabajadores desocupados, familiares de desaparecidos y asambleístas barriales tendieron un puente simbólico hacia los 70, explicando la parábola histórica del neoliberalismo como resultado del golpe militar de 1976. Las organizaciones de Derechos Humanos reivindicaron al militante político que había detrás de cada víctima del terrorismo de Estado, desplazamiento que contribuyó a volver más inteligible al objeto de la guerrilla. En ese sentido, la publicación de La Voluntad en 1997, de Eduardo Anguita y Martín Caparrós, reflejaba el intento de sistematizar los testimonios de la experiencia militante y de repolitizar a las víctimas, como una forma de resistencia frente a la cultura neoliberal. ${ }^{5}$ Lo significativo de La Voluntad no fue su novedad, sino el éxito editorial, que alimentó una industria cultural en permanente crecimiento, gracias al desarrollo del género de no-ficción. En este nuevo contexto, la toma de distancia excesiva parece un anacronismo: el peligro sería el apego apasionado al objeto (la incapacidad de lograr un mínimo de distancia crítica), pero también la antipatía de tratar a los guerrilleros como el antropólogo Bronislaw Malinowsky, que confesaba estar "harto de los negros".

El problema de la aproximación al pasado caliente de los 60/70 no se agota en el binomio empatía/ antipatía, ni es únicamente de orden historiográfico. Si el "objeto" de la historia reciente está lleno de personas que aún viven y son capaces de imponer una narrativa sobre aquella experiencia, nuestra perspectiva no puede ser únicamente la del investigador de archivo. Hay que incorporar las herramientas del antropólogo que realiza su trabajo de campo entre los nativos. Para analizar los modos en que funciona una cultura, Marvin Harris plantea una división esquemática entre pensamiento/materia y actitudes mentales/conductuales. El método para observar estos pares es a través de las descripciones emic y etic, categorías que el antropólogo norteamericano toma del linguista Kenneth Pike. Pike divide el lenguaje humano en phonemics (la fonémica, o sea la lengua como sistema de significados) y phonetics (la fonética, es decir, el soporte material y corporal del habla corriente). Aplicando estos conceptos al análisis social, Marvin Harris identifica la descripción emic como el punto de vista del nativo, y la aproximación etic como el punto de vista del investigador:

Resta el hecho de que los pensamientos y la conducta de los participantes pueden enfocarse desde dos perspectivas distintas: desde la de los propios participantes y desde la de los observadores. Es posible, en ambos casos, la descripción científica — esto es, objetiva - de los campos mental y conductual. Pero en el primero, los conceptos y distinciones empleados por los observadores son significativos y apropiados para los participantes, mientras que en el segundo, lo son para los observadores. ${ }^{6}$

La descripción emic se integra con los enunciados que el nativo estima reales. Gracias a la recolección de esta valiosa información, el investigador aprende categorías útiles para pensar y actuar como un nativo (por ejemplo, el aforismo de John William Cooke acerca del peronismo como hecho maldito del país burgués, la consigna maoísta "el poder brota de la boca del fusil", etc.). La descripción etic, en cambio, se alimenta de la capacidad que tiene el investigador para generar teorías científicas. Por eso se usan categorías externas al objeto de estudio (por ejemplo, la "pulsión de muerte", el “mesianismo" y las "alucinaciones revolucionarias"). En la mirada emic, el informante es el juez del análisis del investigador,

${ }^{4}$ CONADEP. Nunca Más. Informe de la Comisión Nacional sobre la Desaparición de Personas. Buenos Aires: Eudeba, 1985. Según la teoría de los dos demonios, el terrorismo de ultraderecha y ultraizquierda cayó sobre una sociedad paralizada por el miedo, exculpando a la sociedad civil, a la clase política y a las Fuerzas Armadas como institución del Estado de derecho.

${ }^{5}$ ANGUITA, Eduardo; CAPARRÓS, Martín. La voluntad. Una historia de la militancia revolucionaria en la Argentina. Buenos Aires: Norma, 1997.

${ }^{6}$ HARRIS, Marvin. El materialismo cultural. Madrid: Alianza, 1985. p. 46. 
que depende de él para decodificar el lenguaje y los hábitos de los nativos. En la perspectiva etic, por el contrario, es el investigador el juez de las categorías y conceptos empleados en el análisis. Va de suyo que para Marvin Harris no hay que elegir entre uno u otro punto de vista, sino que el abordaje científico de una cultura depende de ambos. ${ }^{7}$ Si echamos una mirada panorámica sobre las diferentes aproximaciones al pasado reciente, todo el campo aparece escindido: memorias y ensayos que comparten el punto de vista del nativo, investigaciones académicas que producen efectos teóricos sobre la configuración de ese mismo pasado. ${ }^{8}$ Para complicar el asunto, los propios observadores parecen estar presos de las categorías nativas forjadas en la transición democrática, por ejemplo cuando se mide el carácter "antidemocrático" y "autoritario" de las organizaciones armadas con el rasero de 1983.

Una solución de síntesis posible de este meollo epistemológico podría partir de la aceptación que todos somos "nativos". Dicho en otras palabras, las categorías desde las cuales escribimos la historia de una sociedad son las propias de una generación y un tiempo determinados, que proyectamos hacia el análisis del pasado de manera consciente o inconsciente. Como afirmaba el historiador francés Jean Chesneaux:

Si el pasado cuenta es por lo que significa para nosotros. Es el producto de nuestra memoria colectiva, es su tejido fundamental (...) Nos ayuda a comprender mejor la sociedad en que vivimos hoy, a saber que defender y que preservar, a saber también que derribar y destruir. La historia es una relación activa con el pasado. El pasado está presente en todas las esferas de la vida social. El trabajo profesional de los historiadores especializados forma parte de esta relación colectiva y contradictoria de nuestra sociedad con su pasado; pero no es más que un aspecto particular, no siempre el más importante, y jamás independiente del contexto social y de la ideología dominante.

Si se pueden aislar y poner en crisis las propias categorías nativas, queda entonces el terreno desbrozado para poder analizar el punto de vista del "Otro", en nuestro caso, el sistema de creencias de las formaciones guerrilleras en la Argentina de la década de 1970. Desde mi perspectiva, aunque me interesa emplear una descripción emic de las prácticas y discursos de las organizaciones armadas, un nivel de teorización etic es útil como tercer paso de la investigación, para poder sacar conclusiones más generales y alcanzar por fin una auténtica distancia (para nada objetiva, aunque si honestamente subjetiva) del pasado reciente. Por caso, si queremos deducir que significaban la traición y el heroísmo en la edad tardía de Montoneros (1974-1980), en principio habría que sincerarse acerca del posmodernismo como dominante cultural de mi propia generación. ${ }^{10} \mathrm{Al}$ imponer una distante mirada post-política y post-ideológica, la traición/heroísmo aparece como un estereotipo negativo que caracteriza a la mili-

\footnotetext{
${ }^{7}$ Desde ya, este modelo nos sugiere varias preguntas: ¿Cuál es la perspectiva "de los propios participantes" en el abordaje emic? ¿Es autóctona, o mediada por el investigador? ¿El observador no es, en última instancia, el juez e interprete que selecciona la información considerada útil, tal como ocurre con el enfoque etic?

${ }^{8}$ En una entrevista a Vera Carnovale se advierte la escisión: “- ¿Por qué elegiste la identidad del PRT-ERP como eje de tu investigación, una perspectiva distinta a la de otros libros? - - - Una insatisfacción frente a los enfoques de los trabajos más conocidos, que hacían hincapié en esta idea de hacer un balance a partir de la derrota de la organización. Se preguntan dónde estuvo el error. Y entonces se cuestionan ciertas estrategias de la lucha armada, por ejemplo. Pero no explican porque los actores actuaron como actuaron, porque llevaron adelante esa línea política, sino que apelan a una mirada prescriptiva, diciendo el error estuvo acá, se debió hacer así o asa. Con el presupuesto de que la historia podría haber sido otra, pensando que la revolución hubiera triunfado si no se cometían esos errores. Hay una premisa que no se coteja con el sistema de creencias partidarias (...) Digo que con este sistema de creencias, de mandatos morales, era imposible que actuaran de otra manera”. Clarín, 19 jul. 2011. Suplemento Ñ.

${ }^{9}$ CHESNEAUX, Jean. ¿Hacemos tabla rasa del pasado? A propósito de la historia y de los historiadores. Madrid: Siglo XXI, 1984. p. 22-23.

${ }^{10}$ JAMESON, Frederick. El posmoderismo o la lógica cultural del capitalismo tardío. Barcelona: Paidos, 1991.
} 
tancia setentista (el discurso de la traición/heroísmo como práctica disciplinaria de las organizaciones armadas). Una vez hecha esta salvedad se puede avanzar en descubrir que significaba efectivamente la traición y el heroísmo para la guerrilla. Por ejemplo, como el detenido-desaparecido que traicionaba a su organización delatando a sus compañeros se convertía en un ser degradado cuya vida ya no era vida, pero que tampoco había sido asesinado, algo así como un "no-muerto" o zombie político (introduciendo de contrabando una categoría nativa del investigador). Por último, queda abierta la posibilidad de pasar de la descripción a un análisis más profundo a partir de una teorización etic, para lo que se puede emplear como herramientas la Antropología de la violencia de René Girard, o el Psicoanálisis de Joseph Campbell y su trabajo El héroe de las mil caras. ${ }^{11}$

\section{La narrativa histórica sobre Montoneros en los 80}

Como parte de nuestro proyecto posdoctoral en torno a la revista Evita Montonera, medio de prensa militante publicado entre 1974 y 1979, interesa en particular indagar la producción historiográfica, periodística y testimonial sobre los últimos años de Montoneros, que englobamos bajo la abarcadora categoría de "narrativa histórica". En la historiografía académica, este período no ha sido desarrollado aún de manera específica, salvo dos capítulos del ya clásico libro de Richard Gillespie ${ }^{12}$ Allí se plantea la tesis de la militarización como punto de inflexión en la historia de la organización armada: Montoneros pasaría de una época jalonada por la actividad política de masas entre 1973 y 1974, donde impulsó agrupaciones como la Juventud Peronista, la Juventud Trabajadora Peronista, la Unión de Estudiantes Secundarios, la Juventud Universitaria Peronista y la Agrupación Evita, a un momento de repliegue, reorganización y creciente aislamiento entre 1975 y 1976. La derrota de Montoneros habría sido facilitada por decisiones políticas como el regreso a la clandestinidad y la militarización de los activistas sociales, al igual que la persecución sufrida durante el gobierno de Isabel Perón. La trayectoria de Montoneros desde el golpe militar de 1976 hasta su definitiva disolución entre 1981 y 1983 es contemplada como una "edad oscura" por varios analistas que ponen énfasis en el militarismo, el vanguardismo, el mesianismo y el terrorismo en el que habría caído ésta organización armada. ${ }^{13}$ Estos trabajos tienen el mérito de advertir la continuidad entre la cultura política de los años 60 y el desarrollo de las grandes organizaciones político-militares en la década del 70, contribuyendo a desplazar el foco de atención del militante al combatiente. Pero también cabe señalar que los acercamientos más novedosos a la última etapa de Montoneros no han sido realizados desde la historiografía académica, sino a través del ensayo político, las memorias militantes, el periodismo de investigación y la novela histórica. El denominador común de estas aproximaciones ha sido la evaluación política y moral de las prácticas y discursos de los Montoneros, o la fascinación literaria por la situación límite del enfrentamiento entre la guerrilla peronista y la dictadura militar. Algo muy diferente, por supuesto, a los balances políticos realizados en la década de 1980, que analizaremos a continuación, siguiendo un orden estrictamente cronológico basado en la fecha de edición original. ${ }^{14}$

\footnotetext{
${ }^{11}$ GIRARD, René. La violencia y lo sagrado. Buenos Aires: Anagrama, 1983; CAMPBELL, Joseph. El héroe de las mil caras: psicoanálisis del mito. Madrid: FCE, 1992.

${ }^{12}$ GILLESPIE, Richard. Soldados de Perón. Los Montoneros. Buenos Aires: Grijalbo, 1998.

${ }^{13}$ A los trabajos de Carlos Altamirano y Hugo Vezzetti ya citados se pueden añadir los de CALVEIRO, Pilar. Política y/o violencia. Una aproximación a la guerrilla setentista. Buenos Aires: Norma, 2005 y LARRAQUY, Marcelo. Fuimos soldados. Historia secreta de la Contraofensiva montonera. Aguilar, 2006.

${ }^{14}$ No vamos a abordar aquí al libro de Miguel Bonasso, Recuerdo de la muerte (1984), ya que Ana Longoni ha realizado un análisis difícil de superar de esta narración testimonial. V. LONGONI, Ana. Traiciones. La figura del traidor en los relatos acerca de los sobrevivientes de la represión. Buenos Aires: Norma, 2007.
} 
El libro de Richard Gillespie Soldados de Perón. Los Montoneros, fue publicado originalmente en inglés hacia 1982, pero su llegada a las librerías argentinas debió esperar a 1987. Se trata posiblemente del primer trabajo académico sobre la izquierda peronista, que conllevó la realización de un peligroso trabajo de campo en la Argentina, entre 1975-1976. Unido a una tradición marxista, Gillespie combinó la descripción de la estructura de clases del capitalismo argentino, con el análisis de la coyuntura política desatada tras el derrocamiento de Perón. En el prólogo a la segunda edición española de 1998, el historiador británico afirmaba sobre su libro: "No he cambiado su tesis fundamental, que me parece todavía válida como explicación del surgimiento y de la derrota de los Montoneros". ${ }^{15}$ Un solo enunciado le sirve para contener a dos momentos que, si tenemos en cuenta los años de desarrollo masivo entre 1972 y 1973, parecen sustancialmente diferentes ¿Cuál es la tesis que menciona el prólogo? Para Gillespie, los Montoneros echaron raíces en las capas medias de la sociedad argentina, pero por su origen pequeńo burgués no pudieron o no quisieron insertarse en la clase obrera, lo que finalmente resultaría fatal para los propósitos de la organización armada:

La experiencia había demostrado a casi todos los activistas de la clase obrera que su fuerza radicaba más bien en el poder colectivo industrial antes que en las armas de fuego (...) No debe pues, sorprender que la guerra de guerrillas urbana en la América Latina prosperase sobre todo en Argentina y Uruguay, países muy urbanizados, con una clase media culturalmente refinada, afectada cada vez más por la reducción de libertades políticas y culturales, a medida que los gobiernos de ambos países iban introduciendo autoritarios controles y medidas económicas impopulares. ${ }^{16}$

A partir de este análisis, Gillespie caracteriza a los Montoneros como una organización elitista, vanguardista y militarista, no tanto por razones de contingencia histórica, sino por los límites inherentes de la pequeña burguesía radical, interpretación que parece influenciada por los escritos de Nicos Poulantzas. ${ }^{17}$ De esta manera, el período $1974-1979$ es reducido al proceso de militarización, que habría aislado definitivamente a la militancia de clase media de su potencial base popular. No pretendemos discutir aquí esa caracterización de los Montoneros, sino llamar la atención sobre la rigidez de la tesis que estructura el relato. ${ }^{18}$ Gillespie participa de las categorías nativas de la izquierda del siglo XX, que atribuyó a la clase obrera un carácter intrínsecamente revolucionario. Con esta premisa que proviene de una perspectiva emic, se mide la radicalidad y la racionalidad del accionar montonero; no obstante, es visible el esfuerzo del autor por partir de una descripción etic, fundamentada en el andamiaje teórico de la obra y sus motivaciones académicas.

Hacia 1984, el periodista Pablo Giussani dio a conocer su libro Montoneros. La soberbia armada. La obra se encuentra a mitad de camino entre las perspectivas etic y emic; el autor declara ser ajeno a Montoneros, aunque exhibe cierta culpa por haber contribuido a forjar una cultura política que desembocó en la opción por las armas. Esta última afirmación es correcta, ya que en la década de 1960 se desempeñó

${ }^{15}$ GILLESPIE, Richard. Soldados de Perón, op. cit. p. 7.

${ }^{16}$ GILLESPIE, Richard. Soldados de Perón, op. cit. p. 106. La analogía entre radicalidad y composición de clase aparece en las p. 76, n. 6, 77, n. 14, 104, 134 y 202. Por otra parte, La supuesta "ingenuidad" de Montoneros en caracterizar a Perón como un líder revolucionario parece tener una impronta generacional (por la inexperiencia de sus cuadros políticos) antes que clasista. En este punto parecería como si Gillespie creyera lo que los Montoneros decían sobre sí mismos; esto se deduce de la profusa cita de fuentes oficiales, en oposición al escaso uso de fuentes reservadas, imposibles de consultar entre 1975 y 1979, cuando el autor desarrolló su investigación.

${ }^{17}$ GILLESPIE, Richard. Soldados de Perón, op. cit. p. 202.

${ }^{18}$ Sobre el problema de la composición de clase de la guerrilla argentina, actualmente contamos con trabajos como los de Pablo Pozzi sobre el PRT-ERP y Javier Salcedo sobre Montoneros, que sugieren una fisonomía organizacional más policlasista. V. POZZI, Pablo. Para continuar con la polémica sobre la lucha armada. Lucha Armada en la Argentina, Buenos Aires, n. 5, p. 44-53, 2006 y SALCEDO, Javier. Los Montoneros del barrio. Buenos Aires: Eduntref, 2011. 
como editor de la revista Che, pero no se puede decir lo mismo de su relación con Montoneros: entre 1973 y 1974 fue secretario de redacción del diario Noticias, vinculado a la organización que asesinó al ex presidente de facto Pedro Eugenio Aramburu. En su libro, Giussani construye a Montoneros literalmente como un objeto antropológico, al compararlos con el pensamiento mágico de una aldea indígena:

Cuando el río crecía y amenazaba desbordar su cauce, los indios de la aldea no hacían lo que racionalmente haría cualquiera de nosotros - huir, treparse a los techos o construir defensas físicas contra el desborde. Lo que hacían era correr con grandes palos a los establos y apalear ferozmente a sus animales, con preferencia a los cerdos, que reaccionaban al castigo con estremecedores chillidos. Era ésta una suerte de tecnología mágica que apuntaba a espantar con el estruendoso lamento de las bestias el espíritu maligno que se había apoderado del río (...) El saber, en esta concepción mágica del universo, no es algo que el hombre común ejercita, sino algo que recibe, una revelación difundida por hechiceros provistos de poderes extraordinarios que les permiten alcanzar, en raros y sublimes momentos de éxtasis, atisbos visuales de ese mundo normalmente invisible (...) Yo había olvidado aquella historia de los cerdos apaleados para calmar al río, hasta que la reviví de pronto, a principios de la década de 1970, en una sugestiva asociación de ideas, al observar las tortuosas relaciones que se desarrollaban en esos años entre los montoneros y el general Perón. ${ }^{19}$

De esta manera, los Montoneros aparecen retratados como unos rebeldes primitivos, opuestos a la racionalidad occidental. La "sugestiva asociación de ideas" se repite a lo largo de todo el libro, llevando al extremo la comparación entre los Montoneros y otras corrientes políticas a través de analogías formales. Para Giussani, el montonerismo es equivalente al fascismo, ya que ambos abrazaron el culto heroico de la acción, la violencia, la muerte y el militarismo. El problema con esta comparación es que el fascismo se convierte en una categoría tan elástica, tan abarcadora, que pierde toda su eficacia explicativa. La analogía entre Montoneros y el fascismo italiano es un tópico retomado por Hugo Vezzetti en su libro sobre la violencia revolucionaria, donde también aparece la referencia a la teoría de Umberto Eco sobre el "fascismo primordial". ${ }^{20}$

En resumen, el libro de Pablo Giussani es ante todo un ensayo político, donde el autor escribe sin documentos y apela a su buena memoria, como si el testimonio personal y la palabra en primera persona fueran garantías de verdad. En este registro, el análisis de la crítica montonera y populista al "liberalismo" sobre el final del libro es brillante: al negar la dialéctica del iluminismo (las contradicciones intrínsecas de la ideología liberal, entre las libertades civiles y la libertad de empresa), la condena en bloque sólo cristaliza y eterniza al liberalismo, sin atacar sus elementos contradictorios. La crítica de Giussani al antiliberalismo ayuda a explicar una parte de la subjetividad combatiente montonera, ya que todos los atributos negativos de la militancia (la traición, el cansancio, la disidencia), son "liberales" e "individualistas", y lo que sostiene a la antinomia liberal/montonero es justamente esa cristalización. Por otra parte, el autor de La soberbia armada afirma que la ética montonera invierte la relación fines-medios: no es el fin el que justifica a los medios, sino el medio de la lucha armada el que justifica al fin de la revolución socialista. Esta "primacía de la técnica" por encima de los fines revolucionarios — visible ya en los años 60 en las páginas de la revista Cristianismo y Revolución—, se erigirá más tarde en un poderoso argumento de los actuales enfoques etic, convertida ahora en violencia pura y simple. ${ }^{21}$

En 1985 salió a la venta la primera y única edición del libro de Carlo Brocato, La Argentina que quisieron. Su autor, con alguna larga experiencia de militancia sindical y en partidos de izquierda, escribió este trabajo en 1980, desilusionado por el panorama político del exilio argentino en Europa. La prosa de

\footnotetext{
${ }^{19}$ GIUSSANI, Pablo, Montoneros. La soberbia armada. Buenos Aires: Sudamericana-Planeta, 1984. p. 13-15.

${ }^{20}$ Ibid., p. 97-98; VEZZETTI, Hugo. Sobre la violencia revolucionaria, op. cit. p. 188-189.

${ }^{21}$ GIUSSANI, Pablo, Montoneros, op.cit. p. 244-250.
} 
Brocato se ubica directamente en el género del ensayo político, y si bien realiza una despiadada crítica a las prácticas de la guerrilla argentina, todavía comparte un lenguaje común con aquellas. Por eso su libro parece que quiere entablar un debate con la izquierda peronista y la guerrilla marxista, entendiendo que formaban parte de una cultura política aún vigente. Aunque parte de una perspectiva emic que se justifica asumiendo una crítica del foquismo desde la izquierda, en realidad este trabajo ya anuncia varios elementos de la toma de distancia etic que se operaría ańos más tarde:

La hipocresía necrológica es ajena al pensamiento revolucionario. La maniobra de colgar la camisa ensangrentada para paralizar la crítica o fomentar la complacencia política no es, por otra parte, un recurso de derrotados: es el hijo legítimo de la maniobra de la víspera, cuando reinaba la euforia. Entonces se aplastaba la controversia o se concitaba la adhesión porque 'el hombre que se juega la vida' está por encima de cualquier objeción. La praxis del coraje no admite cuestionamientos. Esta fue la filosofía política con la que suplantaron el convencimiento por la inhibición psicológica y moral. ${ }^{22}$

Para Brocato, como ocurre con Gillespie, la guerrilla argentina es una creación de la pequeña burguesía radicalizada. Pero el autor de La Argentina que quisieron ańade el culto de la acción (la "praxis del coraje”) en estrecha asociación con el uso político de la muerte. Aquí ya aparecen los primeros elementos para esbozar la hipótesis de un auténtico culto guerrillero de la muerte y la ética del sacrificio, tópicos recurrentes en la renovación historiográfica sobre los 60 y 70. Un capítulo aparte merecen las críticas vertidas sobre la izquierda peronista, particularmente en torno a Montoneros. En primer lugar, el asesinato del general Pedro Eugenio Aramburu en 1970 es definido categóricamente como "el hito primero de la ola terrorista en la Argentina". ${ }^{23}$ Por otro lado, el autor caracteriza a la relación entre Juan Domingo Perón y Montoneros como un malentendido enfermizo:

La cuota mayor, el malentendido por antonomasia, estuvo a cargo de la 'izquierda peronista'. Este malentendido fue, sin exageración alguna, patológico, tanto por las formulaciones delirantes con que fue construido pieza a pieza como por las incontables víctimas sangrientas que caían envueltas por él, vale decir, sin saber a ciencia cierta quien les disparaba. El origen político y social de este equívoco ya lo he señalado. En cuanto a su estructura conceptual, es bastante simple: movimiento peronista hay uno solo (...) Esta actitud irracional, religiosa, está impulsada por una situación: la lógica nos molesta, la racionalidad nos perturba. ${ }^{24}$

Como hemos visto, el autor de La Argentina que quisieron todavía está dialogando con Montoneros y el Ejército Revolucionario del Pueblo (ERP), pero ya anuncia los atributos religiosos, irracionales y patológicos que más tarde desarrollarían autores como Carlos Altamirano, Beatriz Sarlo y Hugo Vezzetti, imponiendo su sello sobre la perspectiva académica del pasado reciente. Carlos Brocato forma parte de aquella generación que atravesó la dictadura militar y encontró en la defensa de la democracia restaurada en 1983 un nuevo proyecto político-cultural.

En 1988, el periodista Juan Gasparini publicó Montoneros. Final de cuentas, un libro en el que se funden el ensayo político, la memoria testimonial y el periodismo de investigación. En pocos años, el

\footnotetext{
${ }^{22}$ BROCATO, Carlos. La Argentina que quisieron. Después de la destrucción estatal y foquista; ¿qué moral civil es posible reconstruir? Buenos Aires: Sudamericana-Planeta, 1985. p. 21-22.

${ }^{23}$ En este pasaje Brocato no aclara cual es el significado del concepto "terrorismo", pero él mismo llama la atención de que la crítica marxista del terrorismo en forma de atentados individuales ha quedado históricamente desfasada. En este sentido, vale la pena ańadir que como se trata de una categoría móvil, Montoneros no puede ser reducido ni al terrorismo individualista anarquista, ni al actual terrorismo fundamentalista, que se dirige de manera indiscriminada contra la población civil. V. NUNEEZ FLORENCIO, Rafael. El terrorismo anarquista (1888-1909). Madrid: Siglo XXI, 1998.

${ }^{24}$ BROCATO, Carlos. La Argentina que quisieron, op. cit. p. 43, 96.
} 
proyecto político de Alfonsín se había deteriorado por el malestar económico, las protestas de sectores de las Fuerzas Armadas y el freno de los juicios a los militares. En este contexto, el trabajo de Juan Gasparini polemiza con el libro de Pablo Giussani, al que seńala como propagandista de la teoría de los dos demonios. Como signo de esas diferencias, Final de cuentas es un ejercicio de memoria planteado como una investigación, que otorga mayor relevancia al análisis de documentos y entrevistas. Éste es quizás el único libro escrito en la época de la restauración democrática que tiene un apartado específico dedicado a la Contraofensiva montonera de 1979-1980. Por el énfasis que da a la memoria y la vivencia personal, pero sobre todo por su enunciación en la primera persona del plural, el autor se ubica claramente en una perspectiva emic:

Buceamos en muchos de sus documentos secretos, leímos publicaciones y reportajes, entrevistamos a diferentes protagonistas, revisamos sus fuentes doctrinarias y analizamos su conducta. Reconstruimos su historia apelando, sobre todo, a la memoria y a la vivencia personal. Y lo escribimos con las tripas (...) Queda así dicho que fuimos parte de la militancia que vio afectada su suerte por aquella experiencia. Compartimos el suplicio en la espantosa celebridad de la ESMA. Sobrellevamos el exilio. Y como la herida sigue abierta, nos sentimos en el deber de arrimar esta contribución al inconcluso debate sobre los Montoneros. ${ }^{25}$

Aunque en Final de cuentas se realiza una crítica de la política armada montonera, el anclaje en las categorías nativas no se desprende de una empatía propiamente "setentista" del discurso de la izquierda peronista. Este modo de ver los hechos sin poder separarse de la propia experiencia generacional se pone de relieve cuando se describen los orígenes de la lucha armada, uniendo este fenómeno a la radicalización de las capas medias juveniles de la sociedad argentina:

La generación política de la que formaban estos estudiantes [los universitarios apaleados en la Noche de los Bastones Largos de 1966] desgarrada desde la niñez por los bombardeos de la Plaza de Mayo y los sindicatos intervenidos a punta de pistola, se vio conmovida por acontecimientos internacionales signados también por la violencia. ${ }^{26}$

Es imposible determinar si el golpe militar que derrocó a Juan Domingo Perón en 1955 significó un trauma infantil para los fundadores de Montoneros, quienes para el padre Hernán Benítez, que los conocía personalmente, procedían de familias antiperonistas. ${ }^{27}$ Aquí Gasparini comparte la misma lectura romántica de la épica montonera, que enmascaró los orígenes no peronistas de la organización creando una narrativa sin fisuras entre la resistencia peronista de la década de 1950, y el surgimiento de las grandes organizaciones político-militares en los años 70. El análisis de la Contraofensiva montonera, sin embargo, es uno de los puntos más fuertes del libro, incluyendo su mirada sobre el delicado tema de la "traición". Como ocurre con Miguel Bonasso en Recuerdo de la muerte, para Gasparini la traición es una forma de degradación humana, que se opone a la categoría moral de la dignidad. Sin embargo, en Final de cuentas la traición no es el eje del relato, aspecto que no impide el hallazgo de sugestivas interpretaciones: según Gasparini, el alto grado de "colaboraciones" es clave para explicar

${ }^{25}$ GASPARINI, Juan. Montoneros. Final de cuentas. Buenos Aires: Punto Sur, 1988. p. 14.

${ }^{26}$ Ibid., p. 46 (el subrayado es mío).

${ }^{27}$ BENÍTEZ, Hernán. Causas y responsabilidades de la ejecución de Aramburu. Cristianismo y Revolución, Buenos Aires, n. 25, p. 4-7, sept. 1970. Cedinci, 2003. CD-ROM. Otra coincidencia entre Gasparini y el relato montonero aparece cuando analiza el Mundial de fútbol de 1978: "Sus consignas provocaron incidentes menores que no afectaron ni la algarabia popular por el fútbol ni el dolor del pueblo por sus desaparecidos", en GASPARINI, Juan. Montoneros, op. cit. p. 189. A pesar de la crítica al accionar de la "M", ¿esta caracterización del sentimiento popular no es similar a la consigna montonera para el Mundial "Argentina campeón-Videla al paredón”? 
la derrota montonera, y al mismo tiempo constituye uno de los fenómenos más inquietantes. Existen relatos acerca de combatientes que aceptaron colaborar con el terrorismo de Estado después de pasar situaciones límite como la tortura, el combate o el intento de suicidio, como si después de transitar por tanto sufrimiento valiera todo. ${ }^{28}$

\section{Conclusiones}

El progresismo socialdemócrata ha dinamitado los puentes con su pasado marxista-revolucionario, y en general con el marxismo como tal (...) Lo esencial del mismo es su desacuerdo con un pasado militante al que aborrece por "mesiánico” y “jacobino", privándolo de cualquier sentido. Es un pretérito inteligible, solo reducible a una época invaginada en su esquematismo o delirio extremistas (...) Encriptada en su "época", la militancia revolucionaria es tan extrańa para la intelectualidad posmarxista como los yorubas y los comechingones.

Omar Acha, El progresismo intelectual argentino (2011)

Hemos pasado revista a la historiografía sobre los Montoneros en la década de 1980, sin restringir ésta a la producción académica, sino relevando también los trabajos de corte periodístico y testimonial, que tienen efectos palpables sobre el sentido común histórico. Hemos intentado desmenuzar esta trama intelectual a través de una investigación emic, entendiendo junto a la antropóloga Mary Black que el objeto de estudio de este tipo de pesquisas es la estructura de los sistemas de creencias. ${ }^{29}$ Los conflictos que se presentan ante los enfoques emic y etic son múltiples: se pueden llegar a deducir hechos de categorías nativas que forman parte de un sistema de creencias, como ocurre con el lazo imaginario entre la militancia juvenil de los 70 y la resistencia peronista de los 50. Por otra parte, también es posible deducir ideas y pensamientos de una teoría científica que no se corresponde con las categorías nativas: es lo que ocurre cuando reducimos la cultura política guerrillera a conceptos como "pulsión de muerte", "alucinación revolucionaria" y "mandato sacrificial". Desde ya, los enfoques de este género no ofrecen solamente confusiones: las categorías nativas se pueden corresponder con la realidad y no solo con un sistema de creencias, como indica la previsión del golpe de Estado de 1976 por parte de Montoneros y el ERP. Al mismo tiempo, las teorías etic pueden iluminar aspectos del punto de vista del nativo que, o bien son inconscientes, o se perciben superficialmente (por caso, la revisión del foquismo que realiza Carlos Brocato en La Argentina que quisieron, o la crítica del antiliberalismo que hace Pablo Giussani en Montoneros. La soberbia armada).

Los tres trabajos que hemos reseñado hasta aquí, dependen de las categorías nativas de su época, prácticamente contemporánea a los hechos armados de las décadas de 1960 y 1970. En Soldados de Perón. Los Montoneros, el politólogo británico Richard Gillespie no solamente realizó una prolija investigación académica sobre la guerrilla peronista. Como militante de las Juventudes Socialistas del Partido Laborista, su trabajo también significó una intervención en el debate político de las izquierdas criticando la viabilidad de la guerrilla urbana. ${ }^{30}$ En 1979, cuando terminó su tesis doctoral sobre la izquierda

\footnotetext{
${ }^{28}$ Juan Gasparini escribe que "Tenían la certeza de que una vez en manos del enemigo ya no quedaba más que defender que la propia vida, puesto que el aniquilamiento de la OPM no se podia evitar con el sacrificio personal”. Ibid., p. 147.

${ }^{29}$ HARRIS, Marvin. El materialismo cultural, op. cit. p. 52.

${ }^{30}$ GILLESPIE, Richard. La contraofensiva fue una locura de los comandantes montoneros. La Nación, 5 jul. 2008.
} 
peronista, el Frente Sandinista de Liberación Nacional tomaba el poder en Nicaragua. Por otra parte, en Europa había varias guerrillas urbanas más o menos activas, como el Ejército Republicano Irlandés (IRA), Euskadi Ta Askatasuna (ETA) y la Fracción del Ejército Rojo (RAF), entre otros. La polémica sobre el accionar político de la guerrilla era algo contemporáneo.

El libro de Carlos Brocato, La Argentina que quisieron, es un ensayo político donde el autor parece hablar "de intelectual a intelectual" (posiblemente con la intelectualidad del exilio, que ha rehusado publicar su libro), como si la derrota de la guerrilla se tratara solamente de un problema de concepciones políticas. Dicho en otras palabras para Brocato parecería que la militancia políticamente correcta fuese un mero subproducto de la teoría revolucionaria. Por el tono polémico de la obra, se hace aún más patente la contemporaneidad del discurso enarbolado por La Argentina que quisieron y la guerrilla, si bien este trabajo ya anuncia todos los elementos de la toma de distancia etic que predomina actualmente en las investigaciones académicas. Tópicos como lo irracional y lo patológico de la guerrilla, que aparecen en el libro de Carlos Brocato, serían retomados por autores como Hugo Vezzetti, quien lo cita extensamente en su libro sobre la violencia revolucionaria. ${ }^{31}$

En el caso de Pablo Giussani, el clima histórico es sensiblemente distinto. El libro Montoneros. La soberbia armada, es un producto típico de la teoría de los dos demonios, que toma a la guerrilla no como objeto del debate político, sino como una advertencia en el epitafio de la lucha armada en la Argentina. El ex redactor de Noticias y de Che da por descontado que la lucha armada y la violencia política han sido arrojadas definitivamente al basurero de la historia, para dejar su lugar al gran relato de la democracia triunfante, consolidada en las urnas hacia 1983. Para Giussani, los Montoneros fueron rebeldes primitivos, una tropa de bárbaros espartanos adoradores de la violencia y el orden militar, textualmente "una conciencia colectiva hechizada por la guerra". Dentro de este marco conceptual, Montoneros. La soberbia armada es parte del engranaje ideológico de la transición democrática, de la ruptura simbólica con un pasado que debe ser dejado atrás para construir un nuevo orden.

En Montoneros. Final de cuentas, Juan Gasparini también realiza una aproximación crítica, pero con la voluntad de no quemar las naves del proyecto emancipatorio que había marcado su pasado militante. De allí su rechazo a la teoría de los dos demonios, aportando un trabajo es tanto un ejercicio de memoria como una investigación periodística. A pesar de este esfuerzo, Gasparini reduce las causas del fenómeno guerrillero a la "radicalización y peronización de los sectores medios". ¿Qué ocurre entonces con los Montoneros del barrio obrero de Moreno, relevados por la investigación de Javier Salcedo? ¿Y las capas medias y obreras que se volcaron a la lucha armada sin adherir al peronismo, como sucedió con los militantes del Partido Revolucionario de los Trabajadores-Ejército Revolucionario del Pueblo (PRT-ERP), la Fracción Roja, las Fuerzas Argentinas de Liberación (FAL), la Organización Comunista Poder Obrero (OCPO) y el Grupo Obrero Revolucionario (GOR)? Aquí el peligro de una mirada "etnográfica” pendiente de las categorías nativas es la apología, y la reivindicación acrítica del testimonio como garantía de acceso a un pasado transparente. Algo de eso sucedería con la narrativa histórica predominante en los años 90', que si bien contribuyó a recuperar la figura del militante político, generó un fetichismo del testimonio como nuevo lugar de la verdad. De la tragedia se pasó en ocasiones a la epopeya, y la víctima del terrorismo de Estado se convirtió en el guerrillero heroico, olvidando las críticas de ensayistas inteligentes y esforzados como Carlos Brocato. La reacción del progresismo intelectual en el campo académico a este revival de los 70 en Argentina no se hizo esperar, y en la década siguiente aparecieron investigaciones y ensayos motivados en una nueva revisión del pasado reciente.

Disponible en: <www.lanacion.com.ar/1026392-la-contraofensiva-fue-una-locura-de-los-comandantes-montoneros>.

${ }^{31}$ VEZZETTI, Hugo. Sobre la violencia revolucionaria, op. cit. p. 82, 96, 121, 122 y 140. 